\title{
La Junta de Alivios de 1669 y las primeras reformas de la regencia
}

\author{
JuAn A. SÁnchez Belén*
}

\section{INTRODUCCIÓN}

Tras el fallecimiento de Felipe IV los políticos españoles tuvieron que enfrentarse a una de las situaciones más graves que podía plantearse a cualquier monarquía absolutista: su gobierno durante la minoría de edad del soberano. Ciertamente, Felipe IV había establecido en su testamento el dispositivo adecuado para que no se alterase la tranquilidad del reino, creando una Junta de Gobierno integrada por cinco relevantes figuras con el cometido de asesorar a su viuda, doña Mariana de Austria, en sus decisiones ${ }^{1}$. Con ello se intentaba suplir la inexperiencia de la regente en los asuntos de Estado y evitar al mismo tiempo el predominio de una facción cortesana, causa del descontento seguro de las otras y, en consecuencia, de inestabilidad política. En la práctica, sin embargo, la medida sirvió de poco. Las competencias jurisdiccionales entre los distintos consejos y Juntas, las presiones de las ciudades y el escaso apoyo prestado por la nobleza y el clero - Maura señala que la terna ministerial procedia de linajes no demasiado ilustres ${ }^{2}$-, fueron factores que dificultaron su gestión tanto como la presencia en sus sesiones del confesor de la reina, el padre Nithard, y las actuaciones de los partidarios de los dos personajes más perjudicados por el estamento del rey, don Juan José de Austria, a quien ni siquiera quiso dar audiencia el monarca mo-

* UNED.

1 Cláusulas 21 a 28 del Testamento de Felipe IV, Madrid 1982.

2 "Llegado al crítico trance de proveer al gobierno de una larga minoridad, la escucriñadora búsqueda de los mejores [...] conducía, irónica, a este desconcertante resultado: tres segundones, un hidalgo de gotera y un Grande de nuevo cuño" (MAura, duque de: Vida y reinado de Carlos II, Madrid 1854, 2. ${ }^{a}$ ed, t. I, p. 65). 
ribundo en su lecho, y el duque de Medina de las Torres, de gran predicamiento en los últimos años del reinado pero postergado por la antipatía manifiesta de doña Mariana -este ministro se hallaba enemistado también con los condes de Castrillo y Peñaranda, miembros de la Junta de Gobierno ${ }^{3}$-.

Este complejo entramado de intereses contrapuestos y de rivalidades personales, junto con la ausencia de un programa de gobierno coherente, no pasó desapercibido a los contemporáneos. Ya en 1665, un autor anónimo advertía a la reina sobre el descrédito en que se vería envuelta la Monarquía española de ser regida por la Junta, dada la «poca unión y conformidad entre los consultantes $[\ldots]$, porque hay envidiosos que piensa ser agraviados por no comprendidos" ${ }^{4}$. Meses más tarde, en 1666, otro escritor daba por hecho la irrisión general que causaba España en las cortes europeas ante “la confusión y falta de gobierno" ${ }^{5}$. El propio Nithard en una serie de memoriales presentados a dona Mariana se lamentará dos años después, quizá exculpándose de las críticas malintencionadas de don Juan José de Austria, su oponente, de las obstrucciones a que fueron sometidos varios de sus proyectos en los Consejos de Castilla y de Hacienda, e incluso en una Junta de Medios que tuvo lugar en su domicilio, "por el útil particular de algunos interesados, de que hay noticias públicas en toda la corte y es notorio a V. M.» ${ }^{6}$.

Por otra parte, el estado de la Monarquía no era precisamente halagüeño: persistia, muy mitigada, es cierto, la contienda con Portugal -diversas voces plantearán la necesidad de finalizar el conflicto reconociendo de iure la independencia del reino sublevado en 1640-; Francia, aprovechándose de la situación, promoverá en 1667 la denominada Guerra de Devolución por la que aspiraba a incorporarse los Países Bajos españoles; el sistema financiero había tocado casi fondo, pues, además de estar las rentas empeñadas con bastantes años de antelación, raro era el asentista que no habia quebrado con la bancarrota de 1662 y el que disponía de capital se mostraba remiso en arriesgarlo concediendo nuevos préstamos sin garantías de devolución; finalmente, Castilla, tras siglo y medio de guerras, exigía rebajas y suspensiones de

${ }^{3}$ Maura, duque de: Op. cit., t. I, pp. 52-55. Sobre Medina de las Torres, Stradling, R. A.: «A Spanish Statesman of appeasement: Medina de las Torres and the Spanish policy, 1639-1670", Historical Journal, XIX (1976), pp. 1-31.

${ }^{4}$ Biblioteca Nacional de Madrid, Sección de Manuscritos, 18659/23, fol. 1v.

${ }^{5}$ Ibidem, 2336, fol. 12.

${ }^{6}$ Ibidem, 8355 , fol. 18 y 6284 , fols. $133-137$. 
tributos, mostrándose las ciudades contrarias al pago de contribuciones si antes no eran aprobadas por las Cortes, y nadie estaba dispuesto a convocarlas por el peligro que entrañaba un acto así para la quietud del país ${ }^{7}$.

Hacia 1665 se imponía, por tanto, una revisión profunda de la política económica de la Corona y en particular de la fiscal. Sin embargo, las acciones emprendidas por el marqués de Salamanca (reducción del gasto público, retenciones de la media anata de juros y mercedes, solicitud de donativos forzosos y voluntarios, etc.) ni solucionaron el déficit crónico ni acabaron con las protestas de las ciudades contra los impuestos, considerados excesivos, desigualmente distribuidos y mal gestionados por aplicarse su importe en asuntos distintos de la defensa. El nombramiento de don Lope de los Rios al frente del Consejo de $\mathrm{Ha}$ cienda - sustituye al conde de Villaumbrosa quien, a su vez, había reemplazado al marqués de Salamanca- tampoco supuso cambios significativos en el sistema fiscal, ya que en ningún momento estuvo dispuesto a rebajar la presión tributaria y menos a suspender los servicios de millones, causantes a juicio de los pueblos del encarecimiento de los géneros de consumo básicos y, en definitiva, de la subida de los salarios y de la baja de los beneficios obtenidos por los agricultores, ganaderos y artesanos, aun cuando se estudió tal posibilidad así como su sustitución por un impuesto que recayese sobre las familias por sus propiedades, según la sugerencia del padre Nithard, partidario también de reformar el procedimiento recaudatorio de los tributos, de eliminar

\footnotetext{
7 Para el reinado de Carlos II, aparte del citado libro del duque de Maura, hay que mencionar el más reciente de KAMEN, H.: La España de Carlos II, Barcelona 1981, aunque respecto a la política exterior y las intrigas palaciegas sigue siendo imprescindible el primero así como el vol. XVIII de la Historia General de España de LAfUENTE, M., Madrid 1869.

El mundo financiero ha sido abordado por DOMinguez ORTIZ, A.: "Algunas notas sobre banqueros y asentistas de Carlos Il», Hacienda Pública Española, 55 (1978), pp. 167-176; MaURO, F.: "Moneda y finanzas de España vistas desde Londres (1670-1740)", I Coloquio Internacional de Historia Económica, Madrid, 1978, pp. 179-189; RuIz MARTiN, F.: "La Banca de España hasta 1782", El Banco de España. Una historia económica, Madrid 1970, pp. 111-152; y SANz AYAN, Carmen: LOS banqueros de Carlos II, Valladolid 1988.

Por lo que se refiere a la hacienda castellana de este periodo, además de lo apuntado en los anteriores trabajos y de las breves consideraciones realizadas por ARTOLA, M.: La hacienda del Antiguo Régimen, Madrid, 1982 y Garcia-CuenCA ARIATI, T.: "El Consejo de Hacienda (1476-1803)", La economia española al final del Antiguo Régimen IV. Instituciones, Madrid 1982, pp. 403-502, conviene citar los trabajos de GarzON PAREJA, M.: La Hacienda de Carlos II, Madrid 1980; Sanz Ayan, C.: "La figura de los arrendadores de rentas en la segunda mitad del siglo XVII. La renta de las lanas y sus arrendadores", Hispania, 165 (1987), pp. 203-224; y SANCHEZ BeLÉn, Juan A.: La política fiscal castellana en el reinado de Carlos II, tesis doctoral inédita, Madrid, UNED, 1986.
} 
gastos superfluos en la burocracia, el ejército y la marina, de suerte que nadie cobrase salarios duplicados, y de combatir la inflación de los precios saneando la moneda de forma permanente ${ }^{8}$.

La firma de la paz con Portugal en 1668 y la desmovilización del ejército de Extremadura apenas benefició a los súbditos, no obstante la creencia, muy generalizada, de que la Corona procedería a rebajar las cargas fiscales por ser menores los gastos militares ${ }^{9}$. Estas frustradas expectativas de alivio tributario serán manipuladas habilmente por don Juan José de Austria en sus ataques a Nithard, incorporándolas a su programa político como reivindicaciones suyas. En la carta que dirige a doña Mariana el 1 de marzo de 1669, aparte de solicitar la destitución del confesor de todos sus cargos y de que en el futuro ninguno pueda inmiscuirse en los asuntos de gobierno -contra este parecer se pronuncia un autor anónimo, probablemente afín a Nithard, cuando recomienda al soberano fiarse sólo de los consejos recibidos en el confesionario, dada la falsedad e injusticia de los ministros ${ }^{10}$-, propone sanear la hacienda, distribuir con equidad las mercedes, proveer con acierto los cargos públicos y alentar una desgravación fiscal y una mayor igualdad en las contribuciones, asumiendo así el sentir de muchos arbitristas para quienes un reino es tanto más rico y poderoso cuanto menor es el gravamen que recae en los súbditos:

"La insoportable carga y exceso de tributos tienen a esta Monarquía en términos de una próxima ruina, siendo su peso tal que aún fuerzas para el gemido le taltan, y asi el alivio de ellas, minorándolas y poniéndolas en un estado fácil y única cobranza, no sólo se debe a la lástima y a la conciencia, sino a su propia conservación y al aumento de las mesmas rentas, porque es máxima muy errada suponer que hacen más ricos a los reyes la multiplicidad de las cargas de los vasallos" "1.

${ }^{8}$ B. N. M., Mss, 8.355 , fol. 108. La misma exposición ofrece en otros pliegos de descargo de las acusaciones de don Juan José de Austria que se conservan en la B. $N$. M., Mss, 8350 , fols. $76-266$.

Noticias sobre la gestión de Nithard en Maura, duque de: Op. cit., l, pp. 191 y ss., y en Matilla TASCON, A.: La única contribución y el catastro de La Ensenada, Madrid, 1947. Por desgracia, no hemos localizado el proyecto del confesor y carecemos de una biografía adecuada del personaje.

${ }^{9}$ B. N. M., Mss, 18659/23, fol. 6 v y 19700/6. Consulta de don Lope de los Ríos, 12 de junio de 1669; Archivo Histórico Nacional, Consejos Surpimidos, legajo 7179. Memoriales de las Iglesias de Castilla y León a la reina gobernadora entre finales de 1668 y comienzos de 1669 .

${ }^{10}$ B. N. M., Mss, 6732, fols. 10-16. Sobre las injerencias del clero en las decisiones reales, Danvila y Collado, M.: El poder civil en España, Madrid, 1885-89, t. III, p. 215.

" A. H. N., Consejos, lib. 878, fols. 46 y ss.; British Library, Egg. leg 327, fol. 129. 
La actitud amenazadora en los alrededores de Madrid del ejército acaudillado por don Juan José de Austria, junto con el descontento de los pueblos, favorecido sin duda por los pasquines sediciosos distribuidos en las ciudades principales por sus partidarios, al que se suma la nobleza y el clero, asimismo afectados por varias disposiciones fiscales que recaian sobre su patrimonio - a la primera se la exige en 1668 un donativo voluntario después de haber servido el año anterior con otro de carácter forzoso, y al segundo se le recarga, por Breve Apostólico de 12 de septiembre de dicho año, los servicios de millones acrecentados por Felipe IV y de los que hasta entonces había quedado exento ${ }^{12}$-, obligan a la regente, presionada por la Junta de Gobierno desacreditada e incapaz de imponerse a los acontecimientos, a cesar al valido e incluso a desterrarle, satisfaciendo una de las reivindicaciones de don Juan José. Simultáneamente, y a instancias del maniobrero conde de Peñaranda, se admite otra de sus exigencias, la formación de una Junta encargada de estudiar y debatir las propuestas de las ciudades, instituciones y arbitristas en orden a solucionar los graves achaques de la Monarquía y procurar el beneficio de los súbditos ${ }^{13}$.

\section{COMPOSICIÓN Y ATRIBUCIONES DE LA JUNTA DE ALIVIOS}

Si bien ignoramos la fecha exacta del Real Decreto mediante el cual se institucionaliza la Junta de Alivios, sabemos que inicia su actividad el

Este memorial to cita el duque de Maura (op. cit., I, pp. 153-154) y lo resume también KAMEN, H., siguiendo al anterior (lbidem, p. 532).

${ }_{12}$ A. H. N., Consejos, leg. 4440 y leg. 7117 , exp. 34. Real Decreto de 28 de septiembre de 1667; B. N. M., Mss, 1322. Consulta de don Lope de los Ríos, 27 de septiembre de 1667; Dominguez Ortiz, A.: Politica fiscal y cambio social en la España del siglo XVII, Madrid 1984, p. 144; Garzon Pareja, M.: Op. cit., p. 348; Maura, duque de: Ibidem, I, p. 103. El Brebe Apostólico se puede localizar en Archivo General de Simancas, Consejo y Juntas de Hacienda, leg. 1251.

${ }^{13}$ B. L. Egg., 327, fol. 119 v.; A. H. N.. Consejos, lib. 878, fol. 47. De los acontecimientos de 1668-1669 se han ocupado LAfUENTE, M.: Op. cit., pp. 27-35; MaURA, duque de: Ibidem, pp. 107-156; y KamEN, H.: Op. cit., pp. 531.532 y «Spanish's first Caudillo: Don Juan José of Austria", History Today, 26 (1976), pp. 584-590. Datos sobre los pasquines sediciosos, A. H. N., Consejos, leg. 7119 , exp. 11 y B. N. M., Mss., 2.582 , fol. 124 y ss. La satisfacción de don Juan José de Austria por las resoluciones de doña Mariana en B. L., Add., 17518. Carta de las Novedades de España, 1665-1669, donde se contiene una carta del principe remitida desde Guadalajara. 
26 de marzo de 1669 cuando se convoca la primera reunión en la casa de su presidente, el inquisidor don Diego Sarmiento de Valladares, presidente también del Consejo de Castilla y de la Junta de Gobierno -el 19 del mismo mes se había expedido a las ciudades una carta de la reina para que indicasen los males del reino y los medios más adecuados para erradicarlos-. Los ministros elegidos para tan alto cometido procedían de los máximos organismos del Estado. Don Pascual Folch de Cardona y Aragón unía a su título de cardenal de. Aragón los cargos de Inquisidor General, regente del Consejo de Aragón y consejero de Estado y de la Junta de Gobierno. Al Consejo de Castilla pertenecian don Antonio de Contreras, don Antonio Monsalve y don Pedro Núñez de Guzmán, conde de Villaumbrosa - el primero había participado en diferentes Juntas de Medios con el conde de Peñaranda; el segundo había sido del Consejo de Hacienda en la década de los cincuenta; y el tercero desempeñó el cargo de presidente de hacienda desde febrero de 1666 hasta septiembre de 1667 y al parecer había suscrito algunos proyectos de Nithard que no puso en práctica ${ }^{14}$ - Don Lope de los Ríos, don Manuel Pantoja, don Jerónimo de San Vitores y don Andrés de Villarán representaban al Consejo de Hacienda, mientras que el marqués de Trocijal hacía lo propio del Consejo de Guerra. Por último, don Francisco Herrera Enriquez Niño de Guzmán y don José Reinalte y Ayala tenían los cargos de corregidor y primer regidor de Madrid. Un selecto grupo de individuos que no desconocian la realidad política de Castilla, tanto en su conjunto como en sus aspectos más individualizados y locales. Sobre el papel, la petición de don Juan José de Austria, relativa a que los miembros de la Junta fuesen «los mayores y más experimentados, celosos y desapasionados ministros" ${ }^{15}$, se habia observado plenamente; para los contemporáneos, sin embargo, la elección no era la más afortunada y pronto surgieron críticas y sátiras donde se les calificaba, a unos, de abúlicos, a otros, de falsos y malandrines, cuando no de parciales, de suerte que los verdaderamente interesados en las reformas a duras penas lograrian imponer sus criterios, presumiéndose quedara todo como estaba antes de su instituto ${ }^{16}$.

${ }^{14}$ Maura, duque de: Op. cit., I, p. 47; Fayard, J.: Les membres du Conseil de Castille à l'époque moderne (1621-1746), Paris, 1979, pp. 83, 118 y 154.

${ }^{15}$ B. L., Egg, 327, fol. 119v; A. H. N., Consejos, lib. 878, fol. 47.

${ }^{16}$ B. N. M., Mss., 8351, fols. 96v-97. El contenido de este papel satírico reza así:

El señor cardenal, santo varón, en todo buen Pascual;

Presidente, sin fruto, será en todo impertinente;

Contreras, hará la Junta burla de sus veras;

Villaumbrosa, pensará muchas y al cabo no hará cosa; 
Estas opiniones, sin duda exageradas, según tendremos ocasión de comprobar, han tenido su impronta en la historiografía dedicada a la Junta de Alivios. Omitida por Garzón Pareja y apenas mencionada por Henry Kamen, su gestión ha sido duramente enjuiciada por el duque de Maura, para quien, en lugar de promover soluciones drásticas, se dedicó a sacrificar, "en holocausto a la diosa nacional de la envidia», a funcionarios, poseedores de títulos de deuda consolidada (juristas) y beneficiarios de oficios municipales heredados o adquiridos por compra. Una interpretación que resalta con tintes sombríos unas medidas dolorosas pero necesarias para sanear la hacienda, en tanto que oculta sus fines de forma deliberada: hacer más rentables los ingresos con el propósito de cancelar parte de la deuda de los pueblos y moderar las cantidades que debían abonar al tesoro para así reactivar la economía, como lo venían exigiendo de antiguo las ciudades y los arbitristas en sus memoriales ${ }^{17}$.

El gran reto que se le planteó a la Junta durante el corto espacio de tiempo que estuvo funcionando (entre marzo y julio de 1669 , fecha en la que por entonces ya estaba don Juan José de Austria en Zaragoza ocupando el cargo de vicario general del reino de Aragón) no fue otro que el conjugar los intereses encontrados en materia fiscal entre la Corona y los súbditos con el fin de aliviarles de contribuciones sin grave menos-

\footnotetext{
Monsalve, hacia si votará lo saludable;

El de hacienda, don Lope de los Rios, a todo humano alivio hará desvios;

Trucijal, nunca dirá palabra de verdad;

Pantoja, votará que el tributo se recoja;

Villarán, Salazar, Isla y Juan Rodríguez lo dirán;

Corregidor, de bueno se hizo ma [o] y pasará a peor;

Reinalte, tendrá en esta Junta menor parte;

La villa y las ciudades consultarán horribles necedades

y todo quedará, con este ruido, en peor estado y mucho más perdido;

La reina santa, haciéndose inocente, cumple con remitirlo a aquesta gente;

Tristes vasalios, Dios os dé consuelo. Pedir a voces el remedio al Cielo.
}

En la British Library, Egg, 327, hay un papel análogo titulado Señores de la Junta de Alivios y pronósticos de los efectos que harán según sus cualidades e influencias, fols. 180 y 181.

17 MaURA, duque de: Op. cit., pp. 160-161. H. Kamen, aunque menciona la Junta apenas añade nada nuevo a lo dicho por Maura (lbidem, p. 532), en tanto que M. GARzON PAREJA llega más lejos aún al omitirla, si bien no desconoce otras Juntas del reinado. Modesto Lafuente alude a la Junta pero sólo como un proyecto y de la que seria su presidente don Juan José de Austria (lbidem, p. 34). Tampoco la menciona A. CANGA ARGÜElles en su Diccionario de Hacienda, Madrid 1833-34, ni ESPEJO ESPINOSA, C.: "Enumeración y atribuciones de algunas juntas de la administración española", Revista de Archivos, Bibliotecas y Museos, 8 (1931), pp. 325-362. 
cabo para el erario, siendo competencia de una Junta de Medios, de la que no tenemos más que vagas referencias, todo lo relativo a la búsqueda de alternativas que posibilitaran el aumento de los ingresos reales. En efecto, la mayoria de las consultas enviadas a la reina para su aprobación - de un total de veintitrés sólo once fueron aceptadas, no sin reticencias ni discusiones de otros organismos - versaron sobre dicho aspecto, aun cuando no se abordaron dos cuestiones de máximo interés: la reforma monetaria y el desempeño de las rentas hipotecadas con los juros, lo cual hubiese situado en sus justos términos el proceso inflacionista y la presión fiscal.

Evidentemente, las circunstancias políticas y financieras por las que atravesaba el país desaconsejaban la realización de proyectos tan vastos. Por un lado, todavía permanecian vivas en el recuerdo las medidas adoptadas en 1664 en el sistema monetario y nadie osaba rectificar sus defectos ante el temor de que los resultados fuesen aún más desastrosos, no obstante algunas proposiciones acertadas como la de Francisco Centani de 1665 o las de fray Juan de Jesús y Sebastián Muñoz Suárez de $1669^{18}$. En cuanto a cancelar o reducir la deuda consolidada, los inconvenientes eran grandes: rebajar el tipo de interés del 5 al 3 o al 2,5 por 100 no se juzgaba oportuno por afectar a los hombres de negocios $y$, sobre todo, a instituciones religiosas y de caridad, muchas de las cuales no contaban con otra fuente de ingresos para costear sus necesidades diarias; amortizar el capital invertido por los juristas resultaba menos viable, porque hubiese originado el desembolso de una suma elevada de dinero (183.944.820 ducados) y el Estado no se encontraba en condiciones de afrontar un gasto semejante -recordemos que en 1667 el total recaudado por el fisco ascendia a 12.793.344 ducados, correspondiendo 9.147.241 ducados al pago de intereses de los juros - ni de transferirlo a los pueblos, agobiados ya de impuestos ${ }^{19}$. Por esto motivo, doña Ma-

${ }^{18}$ El memorial de Centani, probablemente de 1665, en B. N. M., MSs, 6579; el de fray Juan de Jesús, en B.N.M., Mss, 19.700/20; y el de Sebastián Muñoz Suárez, en B. N. M., Varios Especiales, 210/13.

${ }_{19}$ El dato sobre el volumen de juros situados en las rentas y sus réditos en KAMEN, $H$.: Op. cit., p. 567 y en Dominguez Ortiz, A.: Política y hacienda de Felipe IV, Madrid, 1969, p. 325 . Según una relación de 1669 , el valor de las rentas se estimaba en 11.788 .026 ducados, incluidas las rentas de los Maestrazgos, mientras el situado de los juros se cifraba en 9.986.513 ducados, de los que se dejaban sin pagar 1.532.312 ducados por falta de cabimiento en las rentas (A. G. S., C. J. H., leg. 1913).

Sobre los juros, ver los estudios eminentemente jurídicos de BARTHE PORCEL, J.: “Desde el yuro de heredat hasta la desaparición de las cargas de justicia (siglos XIII al XIX). Resumen de una investigación jurídica", Anales de la Universidad de Murcia, 3 (1848-49), pp. 
riana de Austria se limitará a decretar, como venía siendo habitual, la media anata de todos los juros al quitar y la anata entera de los juros cesionarios -en otras palabras, retener el 50 y el 100 por 100 de los intereses que debian percibir los poseedores de estos títulos de deuda consolidada-, exceptuándose los que pertenecian al clero, hospitales y obras pías, si bien ahora, frente a decretos anteriores, no se dará satisfacción a las personas damnificadas, las cuales, sin embargo, podrán solicitar quedar eximidas de la orden general por razones de pobreza, lo que un buen número de ellas consigue en contra de la opinión del Consejo de Hacienda, pues como representa el 13 de mayo de 1669,

"el conceder estas reservas tienen graves inconvenientes, porque lo que principalmente justifica valerse $V$. M. [...] de la media anata de los juros [...] es hallarse las rentas reales tan empeñadas, sin que haya otros efectos que puedan suplir los conocidos y precisos gastos que se hacen en la defensa y conservación de estos reinos, a que de ninguna manera se puede faltar ${ }^{20}$.

\section{EL ALIVIO TRIBUTARIO DE LOS PUEBLOS}

El impacto de la presión fiscal en los súbditos acaparó desde el comienzo una buena parte de las deliberaciones de la Junta, dado que resultaba muy difícil aligerar el gravamen cuando los ingresos estaban comprometidos anticipadamente y la hacienda no disponía de otros recursos para cubrir su déficit -en agosto de 1668 quedaron fuera del presupuesto 4.578 .053 escudos de vellón ${ }^{21}$ - Esta situación se vió acentuada con el Real Decreto de 10 de diciembre de 1668 mediante el cual se derogaba el servicio de quiebra de millones, reputado en 1.300.000 ducados -en 1665 se había rebajado en un 20 por $100-$ y

\footnotetext{
219-287 y Riesco TeRrero, A.: «Los juros de heredad. Estudio histórico, juridico y diplomático del juro", Hidalguia, XXIX, 168 (1982), pp. 220-251, asi como los históricos propiamente dichos de CASTILlo PINTADo, A.: "Los juros de Castilla. Apogeo y fin de un instrumento de crédito", Hispania, XXIII, 89 (1963), pp. 43-70 y PIQUeras Garcia, B. y Molina Martinez, B.: "Los juros en Murcia en los siglos XVI-XVII", Homenaje a Pedro Saínz Rodriguez, Madrid 1986, t. III, pp. 511-522. H. Kamen hace algunas alusiones a este asunto (op. cit., pp. 563, 576 y 578), lo mismo que A. Domínguez Ortiz (Politica y hacienda..., pp. 313-329) y M. ARTOLA (La Hacienda..., pp. 143-157).

${ }_{20}$ A. G. S., C. J. H., leg 1263. Consulta del Consejo, 13 de mayo de 1669 y Consulta del 14 de junio de 1669; RIPIA, Juan de la: Práctica de la administración y cobranza de las rentas reales y visita de los ministros que se ocupan de ellas, Madrid, 1676, p. 295.

${ }^{21}$ Kamen, H.: Op. cit., pág. 561.
} 
se suspendía el cobro de las deudas contraídas por los pueblos con el erario por dicho concepto, evaluadas en nada menos que en 6.000.000 de ducados, si bien como los hombres de negocio tenían librados pagarés por valor de 1.037.433 ducados y no convenía que perdieran tal suma, se estipula prorratearla entre todas las provincias para cancelarla en el plazo de dos años, formalizando las ciudades y villas de cada partido las escrituras oportunas con el Consejo de Hacienda - sólo Madrid queda exceptuada de esta medida, aunque se beneficia de varios descuentos en otras rentas- ${ }^{22}$.

La extinción del servicio de quiebra de millones, que redujo el importe de las rentas provinciales en un 12,14 por 100 -englobamos bajo este término además los servicios de millones, las alcabalas, los cuatro unos por ciento, el servicio real y el papel sellado- ${ }^{23}$, no fue óbice para que las ciudades exigieran otras medidas análogas, atendiendo, según lo expone Ávila en 1669, a que cel aumento o convalescencia universal de los pueblos consiste únicamente en la disminución de algunos tributos" ${ }^{24}$.

Este razonamiento, sin duda justificado, fue asumido por la Junta de Alivios que, como veremos, apoyó en todo momento sugerencias para disminuir el valor total de las contribuciones. No pudo, sin embargo, promover demandas más radicales tendentes a eliminar los servicios de millones, unos por ciento y papel sellado - asi lo solicitan, entre otros, los concejos de Cuenca y Murcia - porque ello hubiese ocasionado unas pérdidas para el tesoro cifradas en 5.363.340,6 ducados anuales (ver Cuadro I), sin contar con que el situado de los juros tendría que anularse o transferirse a otras rentas, lo cual era impracticable por la carga que

${ }^{22}$ A. G. S., C. J. H., leg. 1.250. Real Decreto de 3 de septiembre de 1669; A. H. N., Consejos, leg. 7181, exp. 126; B. N. M., Mss, 19700/6, fols. 297-198 y 8355, fols 19-26 y 108; Real Academia de la Historia, Colección Pellicer, 9-4074, t. XX, fol. 10; RIPIA, Juan de la: Op. cit., p. 148.

${ }^{23}$ La media de los vaiores para el período 1666-1668 fue la siguiente (en ducados):

Alcabalas ......... 1.821.067,5

Cientos ........... 2.046.481,3

Millones ........... 3.093.303,4

Quiebra de Millones ... 1.051.598,7 (con la baja del $20 \%$ desde 1665)

Papel sellado ........ 223.555.9

Servicio Real . . . . . . . 423.699,5

Total ............ 8.659.706,3

(Fuente: A. G. S., Contadurias Generales, legs. 1023-1026, 3913 y 748).

24 A. G. S., C. J. H., Leg. 1251. 
pesaba sobre ellas, no siendo tampoco aconsejable sustituir dichos tributos por un impuesto único, ya que su ejecución implicaba dificultades enormes a la hora de calcular el valor de las haciendas sobre las que recaería el gravamen, si se estimaba oportuno este procedimiento, o de elaborar un censo de todos los súbditos de Castilla, si se optaba por una capacitación o repartimiento por familias ${ }^{25}$.

Buena prueba del estrecho margen de maniobra en que se movía la Junta de Alivios nos la ofrece su fracasado plan para abrogar el servicio de milicias por recaer en los vasallos más pobres y necesitados. El proyecto, defendido con firmeza por don Manuel Pantoja, don Francisco Herrera, don José Reinalte y el conde de Villaumbrosa, fue contestado por don Antonio Monsalve, don Lope de los Ríos y el marqués de Trocijal que se avienen, todo lo más, a rebajar su cuantía, lo que será finalmente aceptado por la reina, según el Real Decreto de 3 de septiembre de 1669 que descuenta a los pueblos 10 ducados por cada soldado, es decir, un 33 por 100 , situándose el repartimiento en 20 ducados $^{26}$.

El alivio obtenido, por pequeño que fuera, no dejaba de ser importante, como también lo era la propuesta de recortar en un porcentaje sustancial el importe de las sisas municipales y reales. Tampoco en este asunto hubo unanimidad en el seno de la Junta, discrepando de forma rotunda don Lope de los Ríos con el argumento, manido pero no por ello falso, de estar las rentas empeñadas en su mayor parte y de temerse la desconfianza de los asentistas a la hora de anticipar dinero a la Corona o de otorgar créditos de los municipios por no quedar afianzado suficientemente el pago de sus préstamos ni el de los intereses devengados ${ }^{27}$. El 23 de julio, no obstante, la reina, avalada por la Sala de Millones que se mostraba favorable al proyecto, resuelve promulgar la baja a la mitad de las sisas reales y municipales, autorizando, en el primer caso, a las ciudades y villas encabezadas a rescindir o mantener su encabezamiento, y estipulando, en el segundo, su extinción una vez concluido el tiempo por el que fueron concedidas ${ }^{28}$.

${ }^{25}$ Ibidem, legs. 1251 y 1912.

${ }^{26}$ B. N. M., Mss, 19700/6, fols. 288v-289v; A. G. S., C. J. H., leg. 1250. Real Decreto de 3 de septiembre de 1669; A. H. N., Consejos, lib. 1474, fol. 31.

${ }_{27}$ B. N. M., Mss, 19700/6. Consulta de la Junta de Alivios, 14 de abril de 1669, fol 281 y voto singular del Señor Presidente de Hacienda, don Lope de los Ríos a consulta de la Sala de Millones de 12 de junio de 1669, fols. 303-309.

${ }_{28}$ Ibidem, fols. 291-293 donde se menciona además el Real Decreto de 23 de julio de 1669. 
CUADRO I. VALORES DE LOS SERVICIOS DE MILLONES, CIENTOS Y PAPEL SELLADO DURANTE EL QUINQUENIO 1666/1670 (en ducados)

\begin{tabular}{|c|c|c|c|c|}
\hline & MILLONES & CIENTOS & $\begin{array}{l}\text { PAPEL } \\
\text { SELLADO }\end{array}$ & TOTAL \\
\hline BURGOS & $129.447,65$ & $121.736,77$ & $18.437,02$ & $269.621,44$ \\
\hline PALENCIA & $53.733,60$ & $44.727,57$ & $10.043,10$ & $108.504,27$ \\
\hline GALICIA & $191.370,31$ & $96.248,19$ & $22.874,01$ & $310.672,51$ \\
\hline LEOON & $103.807,22$ & $93.248,87$ & $17.942,58$ & $214.998,67$ \\
\hline ZAMORA $\ldots \ldots \ldots$ & $20.583,32(1)$ & $19.903,75$ & $1.689,36$ & $42.176,43$ \\
\hline TORO $\ldots \ldots \ldots$. & $39.400,06$ & $16.123,81$ & $1.350,09$ & $56.873,96$ \\
\hline SALAMANCA & $74.858,85$ & $66.430,60(2$ & $4.167,70$ & $145.457,15$ \\
\hline VALLADOLID & $169.009,79$ & $89.996,82$ & $10.058,90$ & $269.065,51$ \\
\hline AVILA & $70.215,40$ & $38.072,18$ & $4.310,56$ & $112.598,14$ \\
\hline SEGOVIA & $142.963,56$ & $64.096,98(3)$ & $3.623,58$ & $210.684,12$ \\
\hline SORIA. & $32.513,13$ & 29.117 .42 & $2.079,82$ & $63.710,37$ \\
\hline GUADALAJARA $\ldots$ & $90.030,49$ & $66.100,22$ & $7.272,84$ & $163.403,55$ \\
\hline CUENCA $\ldots \ldots \ldots$ & $85.447,08$ & $56.797,27$ & $7.537,77$ & $149.782,12$ \\
\hline MUACIA & $53.506,92$ & $17.807,24$ & $4.050,28$ & $75.364,44$ \\
\hline EXTREMADURA . . . & $121.400,70$ & $129.723,57(4)$ & $9.940,56$ & $261.064,83$ \\
\hline TOLEDO $\ldots \ldots \ldots$ & $321.753,58$ & $329.210,50$ & $15.364,85$ & $666.328,93$ \\
\hline MADRID & $282.475,66(5)$ & $243.234,04$ & $20.686,49$ & $546.396,19$ \\
\hline GRANADA & $350.473,52(5)$ & $-(6)$ & $17.803,06$ & $368.276,58$ \\
\hline SEVILLA & $459.053,28(5)$ & $425.126,97$ & $27.288,47$ & $911.468,72$ \\
\hline CORDOBA & $146.293,48(5)$ & $98.778,74$ & $9.987,49$ & $255.059,71$ \\
\hline JAEEN $\ldots \ldots \ldots$ & $92.036,56(5)$ & $-(6)$ & $7.047,46$ & $99.084,02$ \\
\hline TOTAL & $3.093 .303,40$ & $2.046 .481,30$ & $223.555,99$ & $5.363 .340,60$ \\
\hline
\end{tabular}

Fuente: A.G.S., Contadurias Generales, 1266-1269, 1453 y 3913.

(1) Según un documento estaba encabezada en $7.800 .000 \mathrm{mrs}$ (20.855,66 ducados) desde 1666 hasta 1682 (A.G.S., C.J.H., leg. 1367).

(2) La mayoria de los lugares del partido de Ciudad Rodrigo gozaban de exención fiscal.

(3) Sin Cuellar.

(4) Gozan exención fiscal los partidos de Alcántara, Badajoz y Jerez de los Caballeros. Los datos que ofrecemos del valor de la renta son además estimaciones, pues lo recaudado fue menor por bajas a los pueblos e impagos al tesoro.

(5) En $1666 / 68$ el valor del encabezamiento fue de $116.837 .562 \mathrm{mrs}$ (312.400 ducados), en 1669 se rebajó a 236.929 ducados (88.611.305 mrs) y en 1670 subió a 238.250 ducados (89.105.563 $\mathrm{mrs})$.

(6) No hemos podido reconstruir la serie provincial por la fragmentación de los datos disponibles.

Desconocemos el impacto que tuvo en la vida económica castellana este Real Decreto. En principio, cabe suponer que los precios de los géneros alimenticios, sobre todo de la carne, vino, vinagre y aceite, debieron experimentar un fuerte descenso, aumentando la capacidad adquisitiva de los salarios y disminuyendo los costes de manutención a expensas de los empresarios agrícolas e industriales. Lo cierto, sin embargo, es que la escasez de estudios locales nos impide llegar a unas 
conclusiones válidas. Ni siquiera trabajos tan meritorios como el realizado por Adriano Gutiérrez Alonso para el Valladolid del Seiscientos aportan luz suficiente, pues aunque el precio de la carne descendió entre 1668 y 1675 en $4 \mathrm{mrs}$ la libra en las carnicerías mayores -en realidad éste evolucionó desde los $45 \mathrm{mrs}$ de 1669 a los 41 de 1670 , los 33,4 de 1671 , los 28,5 de 1672, los 32 de 1673, los 32,9 de 1674 y los 41 de 1675, para luego dispararse hasta la reforma monetaria de $1680-$, el valor de las sisas y arbitrios municipales se mantuvo constante para el consumidor al por menor, sin que se nos explique las causas de tal comportamiento ${ }^{29}$. Si es seguro, en cambio, que la Corona apenas se vio perjudicada con la rebaja de las sisas reales. Según queda reflejado en el Cuadro II, las cantidades asignadas a las provincias por las sisas nuevas sobre las carnes y tres millones sobre el vino, vinagre y aceite prosiguieron iguales, cuando no fueron mayores, respecto al período anterior, salvo en Córdoba, Murcia y Zamora que se benefician de la rebaja de un 11,7 , un 17,6 y un 10 por 100 respectivamente -en Valladolid y Salamanca sólo se minoran las sisas nuevas de las carnes pero no el servicio de tres millones que aumenta-, en tanto que a Madrid se le descuenta el 24 por 100 de su encabezamiento de millones para el bienio $1669 / 70$.

Otra cuestión que se abordó en estos meses fue el de la deuda de los concejos y la concesión de arbitrios para el pago de las contribuciones. Normalmente, el rey, a través del Consejo de Castilla y a veces del Consejo de Hacienda, autorizaba a los ayuntamientos la facultad de negociar un préstamo, imponer sisas, enajenar tierras concejiles o roturar montes comunales y dehesas para poder cumplir sus compromisos con El erario. Los trastornos que ocasionaban estos recursos a los pueblos y sus vecinos eran enormes. En el primer caso, porque los concejales se endeudaban y dificilmente eran capaces de devolver el préstamo recibido, teniendo que implantar nuevos arbitrios para liquidarlo, agravando asi su precaria situación hacendística. En el segundo, porque al aumentar los municipios de forma artificial los precios del mercado reducia la disponibilidad económica de los grupos sociales menos afortunados y, en

29 Gutiéraez Alonso, A.: Estudio sobre la decadencia de Castilla. La ciudad de Valladolid en el siglo xvI. Aspectos socioeconómicos, Valladolid 1984 (iesis doctoral inédita), t. I, Cuadro 45, p. 252 y Cuadro 50, p. 267. El valor de las sisas nuevas municipales durante los años $1665 / 166$ fue de $4.438 .556 .6 \mathrm{mrs}$ y durante el periodo $1670 / 1674$ fue de 4.657.952,2 (Ibidem, t. II), lo cual no supone forzosamente un aumento en la percepción del recargo fiscal ya que puede tratarse de una venta mayor de los géneros sisados por su menor coste. 
consecuencia, contraía toda la actividad mercantil. En el tercero, porque se privaba a la comunidad del aprovechamiento de los montes y pastos del común, debilitando sus escasos ingresos, sobre todo en épocas de malas cosechas ${ }^{30}$. Para atajar estos perjuicios, la Junta de Alivios esbozará varias soluciones asumidas por la reina. De un lado, moderar del 10 al 6 por 100 los intereses de los créditos concedidos a las ciudades, villas y lugares con cargo a las sisas municipales, aplicándose los dos tercios de la diferencia a rebajar el importe de dicho gravamen y el tercio restante a cancelar el préstamo, bien entendido que una vez saldado se destinará esta suma a desempeñar otros arbitrios ${ }^{31}$. Las sisas municipales ya hemos visto que se redujeron a la mitad. En cuanto a las facultades concedidas para roturar tierras de propios y baldíos, se ordena suspenderlas en el futuro, sin excepción ni pretexto alguno, ya sea por necesidad pública o particular - se revisarán además las licencias otorgadas que no podrán renovarse cuando concluyan-, criterio que se adopta también con la venta de bienes comunales, prohibidas a partir de ahora, aceptándose sólo que se ejecuten las aprobadas anteriormente pero después de ser medidas y tasadas otra vez las parcelas o lotes, cobrándose lo que resultare de más para la real hacienda ${ }^{32}$.

${ }^{30}$ Ruiz Martin, F.: “Procedimientos crediticios para la recaudación de los tributos fiscales en las ciudades castelianas durante los siglos XVI y xVII: el caso de Valladolid", I Coloquio Internacional de Historia Económica, Madrid, 1978, pp. 37-47; VASSBERG, D. E.: La venta de tierras baldias. El comunitarismo agrario y la Corona de Castilla durante el siglo xVII. Madrid, 1983, y Tierra y sociedad en Castilla. Señores, "poderosos" y campesinos en la España del siglo xvil, Barcelona 1987; Garcia Sanz, A.: "Bienes y derechos comunales y el proceso de su privatización durante los siglos XVI y xvII: el caso de tierras de Segovia", Hispania, 144 (1980), pp. 95-127; GOMEZ MENDOZA, J.: "La venta de baldíos y comunales en el siglo xvi. Estudio de su proceso en Guadalajara", Estudios Geográficos, 109 (1967), pp. 499-559. Por su parte, J. López-Salazar piensa que la perpetuación de tierras de baldios no supuso un grave perjuicio a la agricultura castellana ni a los pueblos, si a los grandes ganaderos, motivo por el cual protestaron contra el fenómeno Estructuras agrarias y sociedad rural en La Mancha (siglos XVI-XVII), Ciudad Real 1986, pp. 167-191. Sobre las dificultades financieras de los concejos, GutierRez Alonso. A: "Un aspecto poco conocido de la crisis del siglo XVII. El endeudamiento municipal. El ejemplo de la ciudad de Valladolid", Investigaciones históricas, 6 (1986), pp. 7-38.

${ }^{31}$ B. N. M., MSS, 19700/6. Consulta del 15 de abrit de 1669, fol. 283; A. G. S., C. J. H., leg. 1250. Real Decreto de 3 de septiembre de 1669; A. H. N., Consejos, lib. 1474, fol. 31.

32 A. H. N., Consejos, lib. 1474. Real Decreto de 14 de mayo de 1669; Nueva Recopilación, lib. VII, tít. VII, Auto II; B. N. M.; Mss. 19700/6. Consulta de la Junta de Alivios, 9 de mayo de 1669, fol. 295. 


\section{CUADRO II. VALORES DE LOS SERVICIOS DE VEINTICUATRO MILLONES, TRES MILLONES Y NUEVOS IMPUESTOS SOBRE LAS CARNES (en mrs)}

\begin{tabular}{|c|c|c|c|c|c|c|}
\hline & \multicolumn{2}{|c|}{ VEINTICUATRO MILLONES } & \multicolumn{2}{|c|}{$\begin{array}{c}\text { NUEVOS IMPUESTOS CAR- } \\
\text { NES }\end{array}$} & \multicolumn{2}{|c|}{$\begin{array}{c}\text { SERVICIO DE TRES MILLO- } \\
\text { NES }\end{array}$} \\
\hline & $1665 / 68$ & $1669 / 70$ & $1665 / 88$ & $1669 / 70$ & $1665 / 68$ & $1669 / 70$ \\
\hline BURGOS & 52.895 .494 & 52.895 .494 & 6.556 .200 & 6.556 .200 & 12.523 .800 & 12.523 .800 \\
\hline VALLADOLID & 38.775 .208 & 39.269 .021 & 12.777 .712 & 12.713 .780 & 11.280 .981 & 11.602 .630 \\
\hline SORIA & 7.459 .912 & 7.459 .912 & 1.700 .000 & 1.700 .000 & 3.000 .000 & 3.000 .000 \\
\hline LEON & 22.915 .122 & 22.915 .122 & 3.600 .000 & 3.600 .000 & 12.308 .781 & 12.308 .781 \\
\hline SEGOVIA & .31 .888 .660 & 31.888 .660 & 8.653 .852 & 8.653 .852 & 12.925 .860 & 12.925 .860 \\
\hline GALICIA & 48.760 .000 & 48.760 .000 & 7.812 .498 & 7.812 .498 & 15.000 .000 & 15.000 .000 \\
\hline TORO & 8.161 .842 & 8.161 .842 & 3.038 .618 & 3.038 .618 & 3.535 .166 & 3.535 .166 \\
\hline PALENCIA & 11.020 .722 & 11.020 .722 & 2.704 .027 & 2.704 .027 & 6.371 .621 & 6.371 .621 \\
\hline EXTREMADURA & 25.634 .620 & 25.634 .620 & 9.528 .469 & 9.843 .780 & 10.000 .000 & 10.286 .630 \\
\hline SALAMANCA & 18.030 .952 & 17.938 .093 & 5.749 .790 & 4.666 .030 & 4.416 .706 & 4.841 .810 \\
\hline AVILA & 15.214 .334 & 15.214 .334 & 4.789 .512 & 4.868 .620 & 6.169 .442 & 6.308 .520 \\
\hline z & 4.878 .110 & 4.878 .110 & 1.505 .787 & 1.090 .500 & 1.646 .285 & 1.192 .630 \\
\hline GRANADA & 87.169 .312 & 87.169 .312 & 22.888 .485 & 22.888 .485 & 24.396 .322 & 25.828 .960 \\
\hline SEVILL & 97.038 .547 & 115.893 .769 & 27.188 .122 & 37.393 .020 & 29.644 .138 & 31.036 .200 \\
\hline CORDOBA & 33.629 .875 & 33.629 .875 & 9.476 .810 & 6.841 .610 & 12.178 .043 & 8.359 .820 \\
\hline MURCIA & 1.307 .324 & 1.500 .000 & 2.771 .738 & 2.088 .750 & 4.073 .391 & 3.131 .250 \\
\hline JAE & 23.536 .964 & 23.356 .964 & 4.892 .622 & 4.892 .622 & 5.937 .427 & 6.074 .090 \\
\hline CUENCA & 19.871 .276 & 19.871 .276 & 3.441 .672 & 3.441 .672 & 7.686 .591 & 7.686 .591 \\
\hline GUADALAJARA & 22.793 .506 & 22.793 .506 & 4.859 .100 & 5.158 .460 & 8.159 .090 & 8.540 .712 \\
\hline TOLEDO & 78.208 .523 & 78.414 .123 & 20.379 .914 & 20.580 .010 & 21.105 .813 & 21.105 .813 \\
\hline MADRID $\ldots$ & .116 .837 .562 & 88.858 .430 & - & - & - & - \\
\hline
\end{tabular}

TOTAL . . . . . . . .765.667.865757.703.225164.314.928171.215.522212.359.457212.660.484

Fuente: A.G.S., Cont. Gles, leg. 3913; Dirección General del Tesoro, Inventario 4, leg. 6.

Hay que mencionar, por último, el perdón de todas las cantidades que adeudaban los pueblos de los donativos impuestos desde 1625 hasta 1658. A pesar de la negativa del Consejo de Hacienda que veía en ello un incentivo para no abonarse el valor integro de las contribuciones con el propósito de solicitar y obtener gracias similares, doña Mariana se avendrá en otorgar dicha merced así como en relevar a los 
lugares de justificar el rédito y gasto de los arbitrios utilizados para su pago - sí deberán presentar la contabilidad de los arbitrios que gozan con motivo de los donativos de $1659 / 60$ y $1664 / 65$ - comprendiendo esta norma incluso a las capitales de provincia y de partido que habian sido excluidas por la Junta de Alivios en su propuesta ${ }^{33}$.

Asimismo, el clero se benefició en este año de algunas rebajas en sus exacciones, aunque en ello no intervino para nada la Junta de Alivios. Aparte del descuento sistemático de un quinto que se aplicaba al subsidio y al excusado que pagaba el clero regular y de bonificaciones parecidas a determinados Arciprestazgos ${ }^{34}$, la reina decide, contra el sentir del Consejo de Castilla, no exigir a las Iglesias un donativo autorizado por la Santa Sede en Breve Apostólico de 18 de diciembre de 1668. Meses después, el 26 de julio de 1669, se admiten las quejas formuladas por los obispos respecto de no contribuir en los servicios de ocho mil soldados, dos millones de quiebra, tres millones sobre las carnes, dos millones y medio sobre los pescados y otros tres millones sobre el vino, vinagre y aceite, según la concesión de Clemente IX fechada el 12 de septiembre de 1668, puesto que, como se lee en el despacho dirigido al obispo de Segovia, el único fin de la Corona es privilegiar al estado eclesiástico, aún cuando no se omite señalar "los grandes fundamentos que nos asisten para la ejecución de dicho Breve y que con segura conciencia podríamos usar de él por el aprieto y urgencia de las necesidades públicas [...], asistiéndonos a todo esto el podernos valer de todo el poder de las regalías y mano real» ${ }^{35}$.

${ }^{33}$ B.N.M., MSS 19700/6. Consulta del 9 de mayo de 1669, fols. 293v-295; A.G.S., C.J.H., leg. 1250. Real Decreto de 3 de septiembre de 1669; A.H.N., Consejos, lib. 1474, fol. 31. Sobre la negativa del Consejo de Hacienda a perdonar deudas de los pueblos, B.N.M., Mss, 1322. Consulta del Consejo de Hacienda, 30 de julio de 1667 referida a los alcances del servicio de quiebra de millones. Otros datos en SANCHEZ BELEN, Juan A.: «EI impacto de la independencia de Portugal en la Hacienda castellana", I Jornadas de Historia Moderna, Lisboa 1986 (en prensa).

34 Garzon Pareja, M.: Op. cit., pág. 383; Iturriol Magaña, A.: Estudio del subsidio y excusado (1561-1808). Contribuciones económicas de la Diocesis de Calahorra y La Calzada a la Real Hacienda, Logroño 1987, págs. 102 y 107.

${ }_{35}$ A.H.N., Consejos, leg. 7179 , exp. 14; B.N.M., Mss, 721. Real Despacho al presidente del Consejo de Castilla y obispo de Segovia, 26 de julio de 1669. El Breve Apostólico en A.G.S., C.J.H., leg. 1251. Ver tambièn Dominguez Ortiz A.: Política fiscal y cambio social en el siglo XVII, Madrid 1984. 


\section{LA ADMINISTRACIÓN DE LAS RENTAS PROVINCIALES}

Si los recortes tributarios resultaban esenciales para reactivar la economía y la demografía del reino, lo mismo se puede afirmar de una serie de mejoras en la gestión administrativa de las rentas provinciales, ya que su puesta en práctica excusaba gastos y trastornos a los súbditos y permitía rentabilizar un poco más los ingresos del Estado.

Para Villoslada, en tiempos de Felipe IV, uno de los factores que empobrecía a los castellanos consistía en la multiplicidad de recaudadores como consecuencia de no estar unificada la cobranza de los diferentes tributos en un repartimiento único, de suerte que el monarca percibía un real por cada cuatro o seis que abonaban los vasallos ${ }^{36}$. Este fenómeno, no resuelto entonces de forma satisfactoria, explica los varios testimonios y críticas recogidos en los informes de los embajadores extranjeros y en los memoriales de comienzos de la regencia, contra la diversidad de partidas contables que obstaculizan el exacto conocimiento de los recursos fiscales y la numerosa e inoperante plantilla de recaudadores, tesoreros, contadores, escribanos, administradores y arrendatarios diseminada por toda la geografía castellana. Asi, para el arzobispo de Embrun, el mayor y más sensible defecto del gobierno de la Monarquía española consiste en la incapacidad de sus ministros para ordenar el caos de la hacienda, idea que suscriben los diplomáticos venecianos, desde Mariano Zorzi hasta Carlos Contarini ${ }^{37}$. Por esta causa, Pellicer de Ossau y Tovar exhorta a los preceptores regios enseñar a sus pupilos dicha materia, en tanto que otro autor aconseja en 1665 a doña Mariana de Austria que haga lo posible por eliminar "la incomprensible cantidad de bolsas que tiene esta real hacienda, cuando la del turco, rey de Francia y todos los demás potentados de Europa no tienen más que una [...], porque el dinero es como la harina, que por cuantos más costales pasa mayor menoscabo padece" ${ }^{38}$.

${ }^{36}$ Citado por Gutierrez Nieto, J. I.: "El sistema fiscal de la Monarquía de Felipe IV", La España de Felipe IV, Madrid 1982, pág. 320 (Volumen XXV en la Historia de España de Menéndez Pidal).

${ }^{37}$ Relazioni di Ambasciatori Veneti al Senato, ed de Luigi Firpo, vol. X Spagna (16351738), Turín 1972; MIGNET, M.: Negotiations relatives á la succesion d'Espagne sous Louis $X I V$, Paris 1835-1842, t. II.

38 Peluicer de Ossau y Tovar, J.: Chiron, maestro de príncipes y héroes, dedicado a la enseñanza del Rey N.S.D. Carlos II, Madrid, s.i., s.a, fol. 19-19v; B.N.M., Mss, 10695, fol. 78. 
Tales opiniones inducen a la reina a promulgar, según dictamen de la Junta de Alivios, que los cuatro unos por ciento se administren conjuntamente, no por separado como hasta entonces, bajo un solo arrendamiento, encabezamiento o administración, criterio que también se adopta con las sisas de millones impuestas por la Corona y los municipios, procediendo en este caso los encargados de su cobro a ingresar el porcentaje que corresponde al Estado en las arcas o tesorerías de las provincias y partidos - se excluyen las ciudades y villas portuarias donde se embarcan las mercancias con destino al mercado ultramarino y europeo- ${ }^{39}$.

El alcance limitado de esta reforma, aun cuando no carecía de ventajas para el erario y los contribuyentes -el primero consigue reducir salarios y mejorar la supervisión de las rentas; los segundos obtienen un pequeño alivio al eliminarse algunos ejecutores, cuyos haberes elevaban notablemente el valor de las cantidades que debian abonar-, dejaba inalterado el sistema recaudatorio de las rentas provinciales y sus perjuicios para los lugares, resaltados por éstos una y otra vez con insistencia machacona en sus memoriales, donde, además, abogan por el cese de los administradores generales y particulares a quienes deberán reemplazar los corregidores y las justicias ordinarias. Así se manifiesta Jerez de la Frontera, partidaria a ultranza de proseguir su corregidor al frente del gobierno de las rentas provinciales, no obstante los informes desfavorables enviados al Consejo de Hacienda por los arrendatarios, calificados de parciales por su ambición y codicia. Este criterio, sostenido también por Alcaraz, aparece formulado con claridad meridiana en los memoriales de Avila, Jaén y Granada, cuyo concejo no duda en resaltar los beneficios que se pueden esperar de comisionarse la recaudación de los impuestos a los corregidores y comisarios de millones:

"Corriendo todas por una mano, con un ejecutor que se despache por todos los efectos, cesarán tan grandes vejaciones como reciben los pueblos con tanta multiplicación de ellos que sólo atienden a cobrar sus salarios y que la deuda principal no se pague por tener ocasión de volver más veces y ser más aprovechados, llevándoles dos y tres veces

${ }^{39}$ B.N.M., MSs, 19700/6. Consulta de la Junta de Alivios, 17 de abril de 1669, fols. 288-288v; A.G.S., CJH, leg. 1251. Consulta de la Junta de Alivios, 17 de abril de 1669. La propuesta es admitida por la reina el 29 de abril y a ella se refiere don Lope de los Ríos en su consulta de 12 de junio (B.N.M., Mss, 19700/6, fols. 306v-307). Posteriormente es recogida en el Real Decreto de 3 de septiembre de 1669. 
más que montan los principales, con que no se consigue la paga de lo atrasado ni lo presente" ${ }^{40}$.

Razones no faltaban desde luego a las ciudades, aunque quizá tales demandas oculten el deseo de sus oligarquias de manipular a su antojo la administración de los tributos. El asunto, planteado por los arbitristas ${ }^{41}$, ocupa el interés de la Junta de Alivios, cuyos miembros, como en otras ocasiones, se hallaban divididos en dos grupos antagónicos: el de quienes pensaban que sustituyendo a los arrendatarios y sus agentes y a los administradores nombrados por el Consejo de Hacienda, se lograria un aprovechamiento mejor de las rentas sin perjudicar a los súbditos, y el de quiénes defendían el sistema vigente porque modificarlo supondría, entre otros daños, cuando no el retraso de las recaudaciones, la pérdida de préstamos 0 anticipos tan vitales para afrontar el Estado sus necesidades extraordinarias, sobre todo en tiempo de guerra. Precisamente, para el adalid del inmovilismo, don Lope de los Ríos, uno de los factores

40 A.G.S., C.J.H., legs. 1250-1251 y 1912. Memoriales de Alcaraz, Avila, Jaén, Jerez de la Frontera y Granada.

En un escrito remitido desde Villanueva de la Serena se ejemplifica, con toda precisión, el gasto adicional que revertía en los pueblos la presencia de ejecutores con salarios comprendidos entre 300 y $600 \mathrm{mrs}$ al día, proponiendo reducir a una sola administración las distintas rentas de los partidos. El cuadro que reproduce es muy significativo (B. N. M., Varios especiales, 211/9):

\begin{tabular}{|c|c|}
\hline & $\begin{array}{c}\text { EJECUTOR CON } \\
\text { (mrs/día) }\end{array}$ \\
\hline Por las alcábalas encabezadas & 272 \\
\hline$\ldots \ldots \ldots \ldots \ldots \ldots$, & 400 \\
\hline Por el servicio de millones . . . . . . . . . . & 272 \\
\hline Por el papel sellado & 500 \\
\hline Por los cientos & 400 \\
\hline Por el Servicio Real & 400 \\
\hline Por la Media Anata de oficios ... & 400 \\
\hline Por la sal $\ldots \ldots \ldots \ldots \ldots \ldots \ldots \ldots$ & 400 \\
\hline $\begin{array}{l}\text { Por armar la octava parte de los vasallos, } 30 \text { leguas de los puertos de } \\
\operatorname{mar} y \text { secos } \ldots \ldots\end{array}$ & 500 \\
\hline 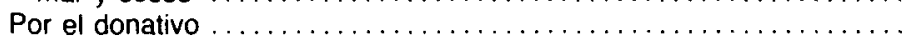 & 500 \\
\hline Por la quiebra de millones & 600 \\
\hline Por el consumo de moneda & 400 \\
\hline Por soldados de presidios & 500 \\
\hline Por repartimiento de torres y puentes & 400 \\
\hline
\end{tabular}

TOTAL

${ }^{4}$ B. N. M., Mss 19700/20, fol. Iv; A. H. N., Consejos, leg. 7.919, exp. 98, fol. 3. 
que a su juicio explica el fracaso del donativo de 1667 radica en la negligencia de las justicias ordinarias encargadas de su cobranza ${ }^{42}$. El propio Consejo de Hacienda, como cabía esperar, tampoco se mostraba entusiasmado con que los administradores fuesen sustituidos por los corregidores. En primer lugar, porque perdería la supervisiór de las rentas al no poder actuar contra ellos deponiéndoles en los supuestos comprobados de abuso o malversación de fondos públicos por depender sus nombramientos del Consejo de Castilla. En segundo término, porque se retrasaria el despacho de la justicia y la cobranza de los impuestos ante la imposibilidad de simultanear con eficacia ambas tareas. Finalmente, porque desde el instante en que los corregidores ocupan sus cargos van "tolerando a los vecinos en la paga de los derechos, y especialmente a los poderosos", con el propósito de granjearse amistades y salir bien parados en los juicios de residencia, de suerte "que en sus manos no sólo descaece el valor de las rentas, sino que aun aquella que se produce no se cobra, siendo tan considerables los débitos que se han causado de esta omisión que si se cobraran pudieran socorrerse en gran parte los apuros presentes ${ }^{43}$.

A pesar de estos argumentos, la reina ordena el 17 de julio de 1669 el cese inmediato de los administradores de las rentas y servicios de millones, asignando su cometido a los corregidores y comisarios del reino quienes asimismo garantizarán el cumplimiento de los derechos adquiridos por los arrendatarios al asumir las funciones antes designadas a los jueces conservadores, que desaparecen - ya el 13 de abril de 1668 se había instituido desempeñasen estos cargos los administradores generales de Madrid, Sevilla, Toledo, Murcia y Granada y los nombrados en cada partido- ${ }^{44}$. Revestidos de estas atribuciones y por las que percibirán un salario digno y proporcionado, los corregidores, a título de "meros ejecutores", por sí o mediante delegados, procederán a cobrar los impuestos apremiando, sin costas excesivas y a los dos meses de haber finalizado el plazo previsto para la entrega de las cantidades recaudadas en las arcas o tesorerias, a las justicias locales, comisionadas a su vez para percibir los tributos de sus respectivas demarcaciones y sobre las que recaerán los salarios de los ejecutores en los casos de morosidad. Para soslayar omisiones y negligencias, los nuevos receptores deberán

${ }^{42}$ Ibidem, 19700/6. Consulta de la Junta de Alivios, 8 de mayo de 1669, fols. 290-291 y 305.

${ }^{43}$ A. G. S., C. J. H., leg. 1250. Consulta del Consejo de Hacienda, 12 de marzo de 1669.

${ }_{44}$ RIPIA, Juan de: Op. cit., pág. 169. 
abonar una fianza, pudiendo el Consejo de Hacienda incoarles expedientes y sanciones como le pareciere oportuno ${ }^{45}$.

La norma, que excluia a Madrid, Sevilla, Toledo, Murcia y Granada por acuerdos suscritos con los diputados en Cortes y a las ciudades más ricas y pobladas de Andalucia, Toledo, La Mancha y Prioratos, no fue bien recibida por los consejeros de hacienda, los cuales, el 30 de agosto, oponen los mismo argumentos y al parecer con el mismo escaso resultado, pues el 3 de septiembre doña Mariana vuelve a ratificarla ${ }^{46}$. Otros sectores tampoco se mostraron muy satisfechos con la orden por no abarcar al conjunto del país. En este sentido cabe mencionar el memorial remitido por el corregidor de Quesada el 10 de febrero de 1670 a favor de la extinción de los administradores generales de las cinco provincias excluidas ${ }^{47}$. Lo grave de ambas actitudes es que poco a poco fueron desvirtuando los objetivos iniciales de la reforma. El 3 de junio de 1670 el Consejo de Hacienda es amonestado por no evitar las molestias que causan los muchos ejecutores despachados a los pueblos para el cobro de sus deudas, y el 13 de septiembre queda sin vigor lo decretado respecto a los jueces conservadores, volviéndose a lo estipulado el 13 de abril de 1668. Cuatro años después, Juan de Ripia, ante la dificultad de prohibir que los citados jueces envien audiencias y ejecutores a instancias de los arrendatarios, recomienda que al menos se procure no coincidan con los despachados por los administradores, siendo preferible incluso que se autorice a los primeros para cobrar el total de las deudas, con independencia de quien sea el destinatario de los valores recaudados ${ }^{48}$.

\section{LOS GASTOS DEL ESTADO}

La política de moderación tributaria puesta en práctica en 1669 requeria, no ya reformas en el gobierno de las rentas reales, sino también

${ }^{45}$ A.H.N., Consejos, lib. 1474, exp. 31; A.G.S., C.J.H., leg. 1251. Consulta del Consejo de 30 de agosto de 1669 donde se reproduce la Real Orden de 17 de julio de 1669.

46 A.G.S., C.J.H., leg. 1251. Consulta del Consejo de Hacienda, 30 de agosto de 1669; Ibidem, leg. 1251. Real Decreto de 3 de septiembre de 1669.

47 A.H.N., Consejos, leg. 7180, exp. 163.

48 RIPIA, Juan de: Op. cit., pág. 233; A.H.N., Hacienda, lib. 7899. Real Decreto de 3 de junio de 1670. 
en el gasto público para compensar el menoscabo que se piensa experimentarán por dicha causa los ingresos del fisco. Al margen de esta consideración, hay que mencionar las críticas formuladas por los arbitristas y las ciudades contra el dispendio - así se manifiestan, por ejemplo, fray Juan de Jesús y la ciudad de Granada- ${ }^{49}$, especialmente en los gastos palatinos, en las instituciones administrativas y en pensiones o mercedes concedidas por la Corona en recompensa de servicios prestados.

La Junta de Alivios no permanecerá sorda ante estas reivindicaciones y entre sus propuestas encontramos un recio ataque al exceso de funcionarios y sus gajes. En conjunto, y sin contabilizar los haberes de los empleados de los tribunales de justicia ni de los adscritos a los Consejos de Estado, Guerra, Inquisición, Cruzada, Aragón, Flandes e Italia, ni de los militares de alta graduación, embajadores, virreyes y gobernadores, el presupuesto de los gastos del personal administrativo para 1669 ascendia a 304.812 ducados, es decir, un 7,9 por 100 del valor líquido de las rentas, una vez deducido el situado de los juros ${ }^{50}$. Con el fin de recortar parte de este gasto y agilizar el funcionamiento de las instituciones, la reina, tras consultar a la Junta de Alivios, ordena el 2 de mayo reducir gradualmente la plantilla de los Consejos, amortizando las plazas vacantes hasta alcanzar el número establecido en las últimas reformaciones, así como eliminar oficios acrecentados y supernumerarios en las secretarias y en las contadurías de hacienda, incompatibilizar sueldos y disminuir el importe de las propinas y luminarias - por lo que se refiere a éstas, su valor se abonará en especie, a razón de cuatro hachas de cera- Los más afectados fueron los secretarios de título, que descienden de 45 a 12, los oficiales de las secretarías de Estado y Guerra -quedan integradas por un oficial mayor, un oficial segundo, un oficial de tercera y otros dos entretenidos-, y los aposentadores de libros, cuyos efectivos se rebajan de 33 a 9 . En cuanto a los salarios, únicamente se remunerará al personal, cualquiera que sea su rango, lo asignado en la nómina y aquellas ayudas de costa que se reputen como tales, pero no lo que se venía pagando en concepto de casa de aposento. Asimismo, se reduce la Junta de Galeras a la planta establecida en 1610, mientras el Tribunal de tasas y retasas de los alquileres de casas de Madrid se compone a partir de ahora de tres miembros, cuando

49 B.N.M., MSs, 10700/20, fol. 1v; A.G.S., C.J.H., leg. 1912

so A.G.S., C.J.H., leg. 1251-1252 y 1915. Relaciones del personal de los consejos y sus salarios realizadas entre el 8 de abril y el 8 de mayo de 1669 . 
antes concurrian seis alcaldes, seis aposentadores y seis regidores con un salario anual de 107 ducados cada uno ${ }^{51}$.

La reforma, sin embargo, pronto tuvo sus excepciones. El 15 de junio se exime al personal de las secretarías de Estado y Guerra, sobre todo en lo relativo a los haberes de los oficiales. Poco más o menos sucede en el resto de los tribunales - el 3 de junio la Junta de Alivios se pronuncia sobre una serie de dudas planteadas por la Junta de Aposentos y el 11 del mismo mes hace lo propio respecto de otras formuladas por el Consejo de Aragón en orden a la aplicación del decreto promulgado por la reina- y hay indicios suficientes de que no se observó la incompatibilidad de salarios y de que prosiguieron nombrándose contadores, secretarios y oficiales e incluso consejeros supernumerarios, con o sin gajes, en parte por las necesidades crecientes de la burocracia estatal que exigia mayor personal para realizar su cometido, y en parte por la estima que se tenia de este tipo de cargos, dadas las posibilidades de promoción social y política que deparaban a sus poseedores ${ }^{52}$.

No prosperó el recorte de los gastos palatinos -en 1669 sólo to librado por mesadas para las Casas Reales se elevaba a 361.058,5 ducados- ${ }^{53}$ ni el de la Casa de don Juan José de Austria a quien, por cierto, la Junta de Alivios quiso privar de algunas cantidades que tenia consignadas en las tres gracias, limitándose doña Mariana a rogarle que solicitase un Breve Apostólico para continuar disfrutándolas, con lo cual remitia la cuestión a la Santa Sede con la esperanza, tal vez, de que Nithard, desde su exilio en Roma, lograria disuadir al Pontífice para que las revocase ${ }^{54}$.

51 Ibidem, leg. 1913. Real Despacho de 30 de abril de 1669; B.N.M., Mss, 19700/6. Consulta de la Junta de Alivios, 16 de abril de 1669. El Real Decreto de 2 de mayo de 1669 en B.N.M., Mss, 19700/6, fols. 311-312v; A.H.N., Consejos, leg. 7179, exp. 81. La reforma de la Junta de Galeras en B.N.M., Mss 19700/6, fols. 295-297.

52 B.N.M., Mss, 19700/6, fols. 310-312, 286v y 300v. La estima de los cargos y el fracaso de las reformas para moderarlos en Dominguez ORTIZ, A.: "Los gastos de Corte en la España del siglo XVII", Crisis y decadencia en la España de los Austrias, Barcelona, 1969 , págs. $75-96$.

53 A.G.S., C.J.H., leg. 1913.

54 B.N.M., MSs, 19700/6. Consulta de la Junta de Alivios, 23 de mayo de 1669, fols. 295-97. No tuvo suerte la reina, pues el embajador ordinario en Roma, el marqués de Astorga, no cesó en su hostilidad hacia Nithard hasta verle reducido en el convento de jesuitas de Tivoli, a seis leguas de la capital, no mostrándose tampoco muy predispuesto a su persona Clemente IX, que sin querer escucharle le excluyó de dos promociones de cardenales. Su sucesor, Clemente $X(1669)$, más sensible a las súplicas de doña Mariana de Austria, le nombró arzobispo de Edessa en el mes de enero de 1672 y en mayo cardenal (Maura, duque de: Op. cit., I, pág. 190-191; Lafuente, M.: Op. cit, págs. 38-39). 
En lo que sí se mostró combativa la Junta de Alivios fue en el asunto de las retribuciones por servicios prestados a la Monarquia. Según un informe elaborado en 1669 , el importe de las mercedes o pensiones situadas en las rentas ascendia a 759.583 ducados, de los cuales quedaban sin cabimiento 176.516 ducados -no se consideran aquí las mercedes situadas en los Consejos- ${ }^{55}$. No obstante su elevado volumen, del que se descontaba la media anata, la Corona nunca quiso atender las sugerencias del Consejo de Hacienda dirigidas a derogar estas donaciones. Motivos humanitarios, en unos casos, y de patronazgo, en otros, lo desaconsejaban. Con todo, el 23 de mayo, un Real Decreto, sancionado por la Junta y por las autoridades fiscales - destaquemos la influencia de don Lope de los Ríos que ya en 1667 había rechazado varias demandas de viudas tendentes a transmitir a sus herederos las mercedes que disfrutaban- ${ }^{56}$, fija la cuantia a las pensiones otorgadas desde 1621 entre 200 y 4.000 ducados - las de 300 ducados se moderan en un tercio y las superiores hasta 8.000 ducados en un 50 por 100 -, no pudiéndose cobrar en plata sino en vellón con el 75 por 100 de premio. El decreto prohibe además que se perpetuen y establece que la diferencia de valor se destine a cubrir algunos gastos estatales ${ }^{57}$. El 14 de junio, sin embargo, doña Mariana decide invalidar su resolución tras una consulta del Consejo de Hacienda donde se planteaba el agravio que padecerian las personas afectadas si se les descontaba también la media anata, ya que dichas gratificaciones habian quedado muy por debajo de su primitivo valor. Sometido a la Junta de Alivios el examen y reconocimiento de los méritos y servicios de quienes gozaban estas pensiones con la finalidad de seleccionar las que podian quedar libres de la rebaja general, este organismo aconseja que se observe lo dispuesto sin vacilaciones, pues de lo contrario «no tendrá execución nada de lo que se consultase en alivio del reino ni llegaría el caso de conseguirse el fin de él" ${ }^{58}$. Los escrúpulos de la reina, seguramente exacerbados por las quejas de sus damas y del clero, la hacen dudar de la utilidad pública de la reforma, siendo preferible a su juicio retener en los momentos de mayor agobio financiero la media anata y otros descuentos, y hasta la renta

${ }^{55}$ A.G.S., C.J.H., leg. 1913. El importe de las mercedes en las nóminas de los consejos se elevaba a 55.000 ducados (ibidem, leg. 1913 y legs. 1250-1251).

${ }^{56}$ B.N.M., Mss, 1322. Consulta de don Lope de los Rios, 5 de diciembre de 1667; Garzon Pareja, M.: Op. cit., pág. 234.

${ }_{57}$ Ibidem 19700/6, fols. 313-314; A.H.N., Consejos, leg. 7179, exp. 23. Según Garzón Pareja, el decreto aconsejando la moderación de las mercedes es de 23 de marzo de 1669 (lbidem, pág. 237).

58 Ibidem, fols. 281v-283; A.G.S., C.J.H., leg. 1263. Consulta del Consejo de Hacienda, 11 de junio de 1669. 
entera, antes que perjudicar indiscriminadamente a los beneficiarios de mercedes - el 30 de abril, empero, se había ordenado extinguir las mercedes situadas en las nóminas de los consejos a título de salario o de gracia- Al final, y tras someter el asunto a una junta particular nombrada a dicho efecto, se aviene a confirmar lo dispuesto el 23 de mayo, reservándose la facultad de exonerar a todas aquellas personas cuyas necesidades así lo aconsejen y precisando que no se detraerá ninguna cantidad de las mercedes reformadas, promesa que será enseguida olvidada, pues en 1670 se autoriza retener la media anata a las que superen los 500 ducados ${ }^{59}$.

\section{DISPOSICIONES CONTRA EL FRAUDE Y LOS PRIVILEGIOS FISCALES}

También la Junta de Alivios se interesó por erradicar el fraude y no permitir exenciones tributarias al amparo de determinados privilegios. En este sentido, una de las primeras medidas planteadas fue la de consumir en todas las ciudades y villas castellanas, con excepción de las que tenian voto en Cortes o eran capitales de partido, los oficios de regidores perpetuos, alféreces mayores, fiscales de justicia ordinaria, alguaciles mayores provinciales de la Santa Hermandad, contadores de particiones $y$ cualesquier otros que conllevaran voz y voto en los ayuntamientos $y$ que habían sido adquiridos por compra desde el año 1630 -en adelante, se advierte, no podrán venderse estos cargos por ningún consejo o tribunal- ${ }^{60}$.

La resolución de doña Mariana, fechada el 9 de mayo de 1669 -el 30 de abril se habia despachado al Consejo de Castilla una orden para que se ejecutara la sugerencia de la Junta de Alivios $-{ }^{61}$, fue bien reci-

59 La orden confirmando el decreto de 23 de mayo de 1669 está fechada el 20 de enero de 1670 (A.H.N., Hacienda, lib. 7899, fol. 12) y en ella se dice que las personas dignas de gozar reserva son los soldados y oficiales inválidos y las viudas sin recursos.

Para la media anata de 1670 sobre las mercedes, A.H.N., Hacienda, leg. 7899, fol. 81v. Real Decreto de 5 de mayo de 1670 y A.G.S., C.J.H., lib. 276. Real Decreto de 17 de enero de 1670.

${ }^{60}$ B.N.M., Mss, 19700/6. Consulta de la Junta de Alivios, 15 de abril de 1669, fols. $284 v-285$.

${ }^{61}$ A.H.N., Consejos, lib. 1474, tol. 16; Nueva Recopilación, Auto V, tít. IX, lib. Ill; Novisima Recopilación, ley XX, tit. VII, lib. VII; Danvila y COLlado, M.: Op. cit., III, pág. 237; Dominguez Ortiz, A.: «La venta de cargos y oficios públicos en Castilla y sus consecuencias 
bida y aplaudida - así lo asegura el corregidor de Quesada- porque facilitaba la consecución de dos objetivos esenciales: evitar que el gobierno municipal estuviera acaparado por unas pocas familias dado el perjuicio que ello ocasionaba a los pueblos y al buen funcionamiento de la justicia -el citado corregidor aboga incluso porque se prive a los alcaldes ordinarios de jurisdicción civil y criminal- ${ }^{62}$; y frenar el acceso de pecheros enriquecidos o de mediano caudal a unos puestos que les eximían de participar en levas forzosas -ya en 1644 Felipe IV habia promulgado un decreto mediante el cual se incluia en las reclutas a quienes habian adquirido "oficios supernumerarios" en los últimos años- ${ }^{63}$ y de pagar impuestos. Como representa don Lope de los Ríos el 12 de junio de 1669, suspender estos cargos, aún cuando acarrean un desembolso importante para la hacienda por la satisfacción que se debe dar a sus propietarios, «es de no pequeño alivio a los lugares, porque además de lo que dejan de contribuir se repartirán entre todos las cargas que llevan sólo los pobres, por eximirse los que tenían oficios comprados y sus familias y amigos, que de ordinario eran los más ricos, y esta desigualdad era más gravosa a los pobres en muchos lugares que la paga de las mismas contribuciones" ${ }^{64}$. Diez años después, sin embargo, el Con-

económicas y sociales", Anuario de Historia Económica y Social, 3 (1970), págs. 105-137, reproducido en Instituciones y sociedad en la España de los Austrias, Barcelona 1985, págs. 146-183. (Este autor, por cierto, fecha la resolución en 29 de mayo de 1669). De la formación de las oligarquias locales mediante la compra de oficios de los ayuntamientos se ha ocupado también TOMAS y VALIENTE, F.: "Las ventas de oficios de regidores y la formación de oligarquías urbanas en Castilla (siglos XVII y XVIII)", Actas I Jornadas de Metodologia Aplicada a las Ciencias Históricas, Santiago de Compostela, 1975, III, págs. 551-568 y "Ventas de oficios públicos en Castilla durante los siglos XVII y XVIII", Gobierno e Instituciones en la España del Antiguo Régimen, Madrid 1982, págs. 151-179.

${ }_{62}$ "La exempciones de alcaldes ordinarios de las ciudades y villas realengas ( $\sin$ tocar por ahora en las de señorio) [...] han puesto en miserable estado las villas a quienes se les ha conçedido, porque se han alçado con el mando una o dos familias o los más poderosos; vinculando en sí, sus casas, hermanos, parientes y amigos, las varas y el gobierno, castigan al que no lo es, haçen lo que quieren los que son de los suyos, y todos mandan, hasta las mujeres, con que hay muchos pecados públicos y delictos que irritan la Justicia Divina, no la hallan los desvalidos en la tierra, cométense muchos robos, muertes y otros atroçissimos, paséanse a vista de los ofendidos, cómense sus ganados los panes, talan los montes, no pagan cosa que considerable sea, mézclanse en las rentas reales, vuélvenlas a repartir, maltratan y echan del lugar al que se les opone, nadie habla ni se atreve, con que recae todo sobre el pobre. Y de mandar V.M. se vuelvan todas las jurisdiçiones de alcaldes que se hubieren eximido de los corregimientos realengos a la cabeça de partido, se repararán tantos daños y saldrán de una esclavitud perpetua en que los tienen, mayormente cuando se eximieron con el dinero de los bienes comunes, y todos lo desean, con que no hay que gastar tiempo en darles satisfacçión" (A.H.N., Consejos, leg. 7180 , exp. 163, apartado 7).

${ }_{63}$ Dominguez Ortiz, A.: La sociedad española..., I, pág. 93.

${ }^{64}$ B.N.M., Mss, $19700 / 6$, fol. 308. 
sejo de Castilla admite el fracaso de este auto acordado por la negligencia de los corregidores en ejecutarle y por las diligencias emprendidas por los interesados, ante lo cual se promulga una Real Cédula el 9 de mayo de 1679 ordenándose cumplir el consumo de los oficios creados desde $1630^{65}$.

Inscrita en esta política hay que mencionar, junto a las rebajas aplicadas a las sisas municipales y reales ya estudiadas - uno de los beneficios que se espera obtener es precisamente reducir el contrabando y la venta ilegal de géneros sisados $-{ }^{66}$, una consulta de la Junta de Alivios solicitando no se concedan franquicias a los embajadores por el consumo de mercancías gravadas con los servicios de millones, observándose, todo lo más, lo estipulado desde antiguo, es decir, que se les abone una cierta suma de dinero en compensación de tales inmunidades de acuerdo con el gasto de sus casas y siempre que no tengan en ellas despensas ${ }^{67}$. El silencio de la reina, harto expresivo, deja por el momento inoperante una medida que, desde luego, hubiese contribuido a liquidar el comercio fraudulento de vino, vinagre, aceite y carne practicado por los criados de los representantes diplomáticos y proscrito por sendas interdicciones de Felipe IV de los años 1653 y 1662 -el 1 de octubre de 1675 las reitera doña Mariana de Austria- ${ }^{68}$, motivo de disturbios frecuentes y violentos en una ciudad donde la delincuencia impone su ley, acogiendo en su seno a pícaros y nobles e incluso a los soldados de la Guardia Chamberga, pues, en palabras del arrendatario del vino de Madrid, sus continuados desafueros le han ocasionado en el transcurso de dos meses unas pérdidas superiores a los 10.000.000 de maravedies, sin olvidar las lesiones producidas a los guardas de la renta, coino la que siete soldados cometieron a las doce de la noche del 21 de agosto a Andrés Hernández, herido de una cuchillada en la cabeza por pretender reconocer unas cabalgaduras que entraban en la ciudad transportando vino por alto ${ }^{69}$. En 1676, sin embargo, parece ser que se llevó

65 A.H.N., Consejos, lib. 1513 , fol. 6.

${ }^{66}$ B.N.M., Mss, 19700/6, fol. 291.

${ }^{67}$ Ibidem, Consulta de la Junta de Alivios, 15 de abril de 1669, fol. 285v. III.

${ }^{6}$ Nueva Recopilación, Auto II, tít. VIII, lib. VI; Novisima Recopilación, ley II, tít. IX, lib.

69 A.G.S., C.J.H., leg. 1275. Informe del arrendador de millones de Madrid, J. Martín Vicente, 23 de agosto de 1669. Sobre alteraciones de orden público provocadas por la Guardia Chamberga, Maura, duque de: Op. cit., I, págs. 157-163, y Gómez Centurión, Carlos: "La guardia Chamberga, don Juan José de Austria y la opinión pública madrileña", Temas de Historia Militar (Comunicaciones al I Congreso de Historia Militar, Zaragoza 1983), Zaragoza 1986, t. I, págs. 250-262. 
a cabo la propuesta de sustituir las franquicias de los embajadores por una cantidad fija con cargo al servicio de millones, lo cual no supuso, como se pensaba, el fin de las despensas ni de los altercados con las justicias ordinarias de Madrid o con los guardias de los arrendadores ${ }^{70}$.

\section{CONCLUSIONES}

Frente al juicio del duque de Maura, seguido sin discusión por otros historiadores -quizás la escasa bibliografía sobre el reinado, y concretamente sobre la regencia de doña Mariana de Austria, justifique tal comportamiento-, la Junta de Alivios, como su propio nombre indica, pretendió en todo instante aligerar el gravamen fiscal y mejorar su exacción, de suerte que no se viesen los pueblos sobrecargados con salarios de audiencias y ejecutores. Sus logros, poco espectaculares en materia tributaria (rebaja a la mitad de las sisas municipales y de los servicios de millones acrecentados por Felipe IV, descuento de un $33 \%$ en el servicio de milicias y perdón de las deudas de los donativos desde 1625 hasta 1658), introducian, sin embargo, alteraciones significativas, pues las cantidades que dejaba de ingresar el tesoro, por moderadas que fuesen, provocaban un aumento del déficit presupuestario de la Monarquía. De ahí que la Junta arbitre el recorte de los gastos palatinos y de la burocracia, reduciendo sueldos, pensiones, funcionarios y criados de las Casas Reales. Por lo mismo, que intente erradicar fraudes y privilegios fiscales obligando a participar en las cargas tributarias, especialmente en los servicios de millones, a quienes distrutaban de un estatuto jurídico particular, aunque luego se les restituyese lo abonado por otras vías -es el caso de los embajadores extranjeros-, o rescindiendo las ventas de oficios con voz y voto en los municipios por quedar exonerados de los repartimientos, cuando no por las injusticias que cometen contra los vecinos distribuyendo a su capricho las cuotas fiscales asignadas a la comunidad.

No se puede afirmar, desde luego, que las propuestas de la Junta de Alivios fuesen revolucionarias y, por tanto, que contribuyesen a solu-

70 Decimos que se ejecutó en este año porque en un documento fechado el 21 de agosto de 1683 se mencionan las cantidades que se adeudan a los embajadores extranjeros con cargo a las arcas de millones de Madrid por sus franquicias en el consumo de artículos afectados por las sisas desde el año 1676 hasta fin de septiembre de 1682, y no hemos encontrado ninguno similar en años precedentes (AGS, CJH, leg. 1462). 
cionar los graves desajustes que presentaba la estructura económica de Castilla: dejó sin plantear la reforma monetaria, soslayó el problema acuciante de la deuda consolidada y no defendió con vigor las sugerencias de las ciudades para abrogar determinados impuestos, tales que el papel sellado, los servicios de millones y los cuatro unos por ciento -apenas hay peticiones dirigidas a suspender o moderar las alcabalas, to cual se comprende porque en el conjunto de las rentas provinciales suponían tan sólo un 21,09 por 100 , frente al 61,88 por 100 que representaban aquellos o el 4,89 por 100 del servicio real ${ }^{71}$. En cualquier caso, su actividad estuvo muy condicionada, no ya por las circunstancias generales del reino, sino por la existencia de dos sectores de opinión bien diferenciados: por un lado, las oligarquías urbanas poseedoras de tierras y ganados, interesadas en monopolizar la administración de las rentas y en limitar las regalias de la Corona en esta materia; por otro, los hombres de negocios, incardinados a veces en el gobierno de los municipios y, sobre todo, en el Consejo de Hacienda - aqui al parecer por iniciativa de don Lope de los Ríos-, contrarios a toda reforma que minorase los valores de los tributos o implicase cesión de su gobierno en favor de las ciudades o de las justicias ordinarias ${ }^{72}$. Una pugna que, si pospuso empresas de mayor envergadura para cuando la ocasión resultase más propicia a los intereses de cada una de las facciones en liza, permitió realizar ciertos cambios sin perjudicarles en exceso, beneficiando, al menos sobre el papel, a los sufridos vasallos de Castilla en quienes había recaído y seguia recayendo el peso de la monarquía de los Habsburgo.

${ }^{71}$ Ver nota 23. Según otro documento, en el que no aparece ya el servicio de quiebra de millones, los porcentajes fueron los siguientes: alcabalas, 28,17 por 100; servicio real, 4,62 por 100; papel seliado, 2,96 por 100; millones, 36,61 por 100; cuatro unos por ciento, 27,61 por 100 . (El valor global de estos tres últimos tributos representaba el 67,18 por 100).

72 Sanz Ayan, C.: Op. cit., págs. 434-450. Sobre la toma de conciencia de los grupos intermedios de la sociedad castellana, MARAVALL, J. A.: Poder, honor y élites en el siglo XVII, Madrid 1979, págs. 251-302. 